UDC 316.4.06

LBC 60.59

\title{
POLITICALLY ACTIVE YOUTH: STRATEGIES OF POLITICAL PARTICIPATION IN THE CONTEXT OF THE SOCIAL FUTURE IMAGE ${ }^{1}$
}

\author{
Yana V. Didkovskaya \\ Ural Federal University, Yekaterinburg, Russian Federation \\ Dmitriy V. Trynov \\ Ural Federal University, Yekaterinburg, Russian Federation
}

\begin{abstract}
The research focuses on a certain aspect of political activity of young people - the image of the social future. The target sector is young people who actively manifest themselves in the social and political sphere: pro-government and opposition-minded groups of young people. The image of the social future is considered as one of the key components of the social well-being of young people reflecting their ideals and expectations. At the same time, the choice of the strategy of active political involvement of young people is analyzed through the prism of subjective states - mood, well-being, expectations.

Two groups of respondents took part in the survey: activists of pro-government organizations, as well as regional youth parliaments, governments, youth public chambers $(n=300)$; representatives of modern youth protest, primarily volunteers of the "Progress party" and "Libertarian party" $(\mathrm{n}=300)$.

Ccomparing the images of the desired and expected future of politically active youth, a mismatch between their social ideals and the expected direction of events in the future was revealed. It mainly concerns the prospects for economic development and is much more pronounced among opposition activists. For opposition youth, the contradiction between the desired and expected future, in addition to the dissonance in economic development, affects the sphere of legal relations: an important landmark is a humanistic society tolerant of minorities, and the most likely expected event is the restriction of the rights and freedoms of citizens. The imbalance between social ideals and social expectations causes pessimistic attitudes among young people and dissatisfaction with the current situation in various spheres of life.

Such circumstances of the choice of the strategy of political participation as orientation to the social ideal, ideological and political identification, readiness for conflict behavior are revealed. All of them simultaneously act as watershed lines between groups of pro-government and opposition activists.

The image of the social future determines the choice of the strategy of political participation implemented by young people. "Active adaptation", more typical for a group of pro-government youth, involves the use of the mechanisms proposed by the authorities to engage them in politics. The "activist-protest" strategy is implemented by opposition-minded youth, its important indicator is the willingness to go to conflict in various life situations.

As a forecast, the authors put forward the following thesis: with the declining level of social well-being, among politically active youth, the number of transitions from state-approved forms of political participation to protest ones will increase.
\end{abstract}

Key words: political activism, image of social future, social expectations, political socialization of youth, protest moods, political participation, strategies of political participation.

УДК 316.4 .06

ББК 60.59

\section{ПОЛИТИЧЕСКИ АКТИВНАЯ МОЛОДЕЖЬ: СТРАТЕГИИ ПОЛИТИЧЕСКОГО УЧАСТИЯ В КОНТЕКСТЕ ОБРАЗА СОЦИАЛЬНОГО БУДУЩЕГО ${ }^{1}$}

\author{
Яна Викторовна Дидковская
}

Уральский федеральный университет, г. Екатеринбург, Российская Федерация 


\section{Дмитрий Валерьевич Трынов}

Уральский федеральный университет, г. Екатеринбург, Российская Федерация

Аннотация. В исследовательском фокусе статьи находится определенный аспект политической активности молодежи - образ социального будущего. В качестве объекта выбрана молодежь, активно проявляющая себя в общественно-политической сфере: провластно и оппозиционно настроенные к власти группы молодежи.

Образ социального будущего рассматривается как один из ключевых компонентов социального самочувствия молодежи, в котором отражаются ее идеалы и ожидания. При этом выбор стратегии активного политического вовлечения молодежи анализируется через призму субъективных состояний - настроение, самочувствие, ожидания.

В опросе приняли участие две группы респондентов: в первую вошли активисты провластных организаций, а также региональных молодежных парламентов, правительств, молодежных общественных палат ( $\mathrm{n}=300)$; во вторую - представители современного молодежного протеста, прежде всего волонтеры «Партии прогресса» и «Либертарианской партии» $(\mathrm{n}=300)$.

Сопоставив образы желаемого и ожидаемого будущего политически активной молодежи, мы выявили рассогласование между ее социальными идеалами и ожидаемым направлением развития событий в будущем. В основном оно касается перспектив экономического развития и выражено намного острее среди активистов-оппозиционеров. При этом для оппозиционной молодежи противоречие между желаемым и ожидаемым будущим, кроме диссонанса в экономическом развитии, затрагивает сферу правовых отношений: важным ориентиром выступает гуманистическое общество, терпимое к меньшинствам, а наиболее вероятным ожидаемым событием - ограничение прав и свобод граждан. Дисбаланс между социальными идеалами и социальными ожиданиями обусловливает пессимистические настроения среди молодых людей и неудовлетворенность текущей ситуацией в различных сферах жизни.

Вскрыты такие обстоятельства выбора стратегии политического участия молодых активистов, как ориентация на социальный идеал, идейно-политическая идентификация, готовность к конфликтному поведению. Все они одновременно выступают линиями водораздела между группами провластных и оппозиционных активистов.

Образ социального будущего обусловливает выбор стратегии политического участия, реализуемой молодежью. «Активная адаптация», более характерная для группы провластно настроенной молодежи, предполагает использование предлагаемых властью механизмов вовлечения в политику. «Активистско-протестная» стратегия реализуется оппозиционно настроенной молодежью, ее важным индикатором выступает готовность идти на конфликт в различных жизненных ситуациях.

В качестве прогноза выдвинут тезис о том, что при снижающемся уровне социального самочувствия среди политически активной молодежи возрастет количество переходов от одобряемых государством форм политического участия к протестным.

Ключевые слова: политическая активность, образ социального будущего, социальные ожидания, политическая социализация молодежи, протестные настроения, стратегии политического участия.

\section{Введение}

Современное общество сложно представить без динамично функционирующей политической системы, основу которой составляет правовое государство с демократическими институтами и гражданским обществом. Последнее, в свою очередь, выступает механизмом не только контроля государственных структур и оценки их эффективности, но и рекрутирования в общественно-политическую сферу наиболее активных участников. Политическое участие граждан при этом составляет необходимую основу поддержки демок- ратических политических институтов, развитие и жизнеспособность которых определяются активностью как социальных групп, организаций, так и отдельных индивидов.

Особое место в этом процессе занимает молодежь как социальная группа - носитель потенциала новых идей, ценностей и образа будущего. За счет молодежи происходит как идейное, так и кадровое обновление политической системы. Ее специфика как субъекта политического процесса заключается в следующем: политическая активность молодежи, с одной стороны, направлена в будущее, ориентирована на перспективу, а с другой - во 
многом определяется субъективными оценками этой перспективы. Учитывая, что политически активная молодежь является источником пополнения политической элиты, исследование ее социальных идеалов и ожиданий позволяет с определенной долей вероятности прогнозировать общественно-политическое развитие страны.

Политическая активность молодежи достаточно давно находится в фокусе внимания ученых. Анализ социологической литературы позволил нам выделить следующие подходы к исследованию политической активности молодежи.

Политическая активность молодого поколения в рамках комплексных исследований молодежи как социальной группь. Политическая активность анализируется как один из аспектов самореализации молодежи наряду с образованием, профессиональной деятельностью, досугом и другими. В рамках такого подхода, назовем его комплексным, политическая активность изучается как деятельность, основанная на осознании своих социально-групповых интересов, взглядах, позиции в обществе по оказанию влияния на институты власти и принятие политических решений [Елишев 2013].

Большинство комплексных исследований российской молодежи фиксируют проблему ее политической пассивности, причина которой кроется в особенностях развития политической системы общества. Так, Горшков и Шереги, описывая сложившуюся ситуацию в отношениях между государством и молодым поколением, приходят к выводу о значительной отстраненности молодежи от политики. Причину такого положения социологи видят в слаборазвитой самоорганизации молодежи, что в конечном счете приводит к абсолютизации «попечительской роли государства и роста патерналистских установок молодежи» [Горшков, Шереги 2010, 143]. Как отмечает Смакотина, политическая активность молодежи нередко замораживается вполне осознанно в угоду правящему классу, который не заинтересован в становлении молодежи как реального субъекта политики [Смакотина 2009, 15].

Гражданская культура и политическая социализация молодежи. Второй под- ход представлен исследованиями, рассматривающими политическую активность молодежи в контексте формирования гражданской культуры и патриотического воспитания. Их методологическую основу составляют ставшие классическими труды Г. Алмонда и С. Вербы, в которых постулируется, что становящаяся гражданская культура - это культура участия [Алмонд, Верба 2014]. В рамках подхода поднимается комплекс проблем, связанных с активностью и компетентностью различных подгрупп молодежи, их стратегиями представительства в органах власти и отстаивания интересов, доверия и недоверия политическим институтам. Особое место отводится изучению политической социализации молодежи [Милорава 2017] и реализации государством функции гражданского воспитания при помощи таких институтов, как школа, вуз, армия и т. д. [Санина 2016].

Образ социального будущего молодежси. К третьему подходу мы отнесли исследования образа социального будущего молодежи, который интерпретируется как комплекс социальных ожиданий, идеалов, надежд, ориентиров, представлений молодежи о перспективе, основная функция которого состоит в том, что на его основе молодые люди выстраивают как свои личные, так и групповые стратегии, жизненные программы [Трынов 2012].

Социологические работы, посвященные социальному будущему, составляют часть общей дискуссии о путях социально-политического и экономического развития общества. В них молодежи отводится особая двуединая роль, с одной стороны, хранителя «социального гена» общества, его национальнокультурных свойств, а с другой - нового источника модернизации и самой ее основы [Гаврилюк и др. 2016]. При этом отмечается нарастание негативных экономических [Александрова, Ненахова 2017] и социальнодемографических тенденций [Соболева, Смирнова, Чудаева 2016], приводящих к проблемам, решение которых имеет отложенный характер.

Протестные настроения как форма политической активности молодежи. Отдельно следует выделить такое направление, как исследование протестных настроений 
и активности различных социальных групп [Яницкий 2012; Артюхина 2017]. При этом нередко протестные настроения сопоставляют с проявлением крайних форм политической активности, доходящих до экстремизма [Ефанова 2011]. Чаще всего протест, переходящий в политическую форму, связывают с комплексом факторов, имеющих глубинные и устойчивые негативные социально-экономические тенденции. Доказана связь между неустойчивым положением работника на рынке труда, отсутствием гарантий занятости и протестным потенциалом [Campante, Chor 2012; Kofi, Melvin 2013]. С.Н. Чирун усматривает прямую зависимость между протестными настроениями, социальной структурой и вертикальной социальной мобильностью: «Нежелание организовывать социальные лифты для представителей всех слоев общества, а не только для своих сторонников, неизбежно провоцирует экстремистское поведение у молодых людей, “выпавших” из дискурса власти» [Чирун 2011, 45]. Поскольку перед молодежью остро стоит ряд социальных проблем, особенно связанных с материальным положением и перспективами трудоустройства, данная социальная группа нередко выступает как ядро и основной драйвер протеста.

При всем многообразии социологических работ, посвященных политической активности молодежи, отмечается дефицит исследований, касающихся такой подгруппы, как молодежь, вовлеченная в деятельность общественно-политических движений и политических партий. Чаще всего авторы обращаются к изучению уровня политической активности (интереса к политике, информированности, участия в выборах), молодежи в целом или ее формально регистрируемых подгрупп - студентов, старшеклассников, жителей определенного региона (среди этих категорий политически активная молодежь представляет, как правило, довольно узкий слой и остается недоступной для более детального анализа). Наиболее активная часть молодежи, которая и формирует политический дискурс молодого поколения, остается вне поля зрения теоретического и эмпрического исследования.

Цель нашей статьи заключается в анализе актуального образа социального будуще- го политически активной молодежи как контекста, в котором формируются стратегии ее политического участия. При этом мы посчитали важным отразить в статье следующие моменты: во-первых, определить формы идейно-политической самоидентификации и их значимость для политически активной молодежи; во-вторых, провести сравнительный анализ мотивов общественно-политического участия активистов-сторонников и активистовоппозиционеров (провластной и оппозиционной молодежи); в-третьих, соотнести компоненты образа социального будущего молодежи с различными формами ее политической активности и определить влияние актуального образа будущего на выбор молодежью стратегий политического участия.

\section{Дизайн исследования}

Особенностью нашего исследования является то, что в качестве объекта избрана молодежь, активно проявляющая себя в общественно-политической сфере. Учитывая, что политическая активность, как правило, выражается в двух основных формах (поддержки и протеста), мы заранее ограничили объект исследования двумя группами политически активной молодежи - провластно и оппозиционно настроенной молодежью. Нас интересует образ социального будущего как аспект политической активности молодежи, поскольку он связан с формированием ориентаций на перспективу: посредством своей политической активности молодежь стремится реализовать то «желаемое социальное будущее», которое заключается в ее социальных идеалах [Дидковская, Дулина, Трынов 2018]. При этом социальные идеалы могут входить в противоречие с социальными ожиданиями молодежи, то есть ее «вероятным или ожидаемым социальным будущим». Мы полагаем, что рассогласование идеального и ожидаемого является внутренней предпосылкой для негативного социального самочувствия и пессимистичных настроений относительно макро- и микроперспектив. Пессимизм в оценке траектории развития общества и своей личной траектории в этом обществе, в свою очередь, обусловливает выбор молодежью протестных 
стратегий вхождения в общественно-политическую жизнь.

Для реализации поставленных задач нами проведено выборочное исследование политически активной молодежи в возрасте до 30 лет методом анкетного опроса на платформе Google-форм. Исследование охватило молодых активистов политических организаций и движений Уральского федерального округа. Использована целевая выборка $(\mathrm{N}=600)$. Опрошены две группы респондентов по 300 человек каждая. Респонденты первой группы отбирались на основе участия в созданных государством каналах политической активности, считающейся желательной и допустимой с точки зрения действующей власти, рекрутинг респондентов производился через такие организации, как «Молодая гвардия “Единой России"», а также региональные молодежные парламенты, правительства, молодежные общественные палаты. Респонденты второй группы были рекрутированы из организаций, регулярно оппонирующих власти с самых разных идейных позиций, в нее вошли представители современного молодежного протеста, прежде всего волонтеры штабов А. Навального и либертарианской партии. Внутриорганизационные коммуникации вполне позволили опросить необходимое число респондентов, не прибегая к дополнительным методам рекрутинга. Исходя из выбранной стратегии политической активности, первая группа респондентов получила рабочее название «активисты-сторонники», вторая - «активисты-оппозиционеры».

Анкета состояла из четырех основных блоков вопросов. Блок «Политическая самоидентификация» подразумевал определение респондентами своей политической позиции из спектра идеологий, представляющих наиболее устоявшиеся в общественном сознании идейно-политические течения. Следующий блок анкеты «Мотивы политического участия» предполагал множественный выбор (не более 3 вариантов) из перечня возможных мотивов включения респондентов в политическую деятельность. Блок «Образ социального будущего» представлен двумя индикаторами: общественный идеал, или «желаемое социальное будущее», измерялся как множественный выбор (не более 3 вариан- тов) направлений или ориентиров социальноэкономического и социально-политического развития общества; социальные ожидания, или «ожидаемое социальное будущее», - как оценка респондентами вероятности наступления позитивных и негативных политических и социально-экономических событий по шкале от 1 до 5. Блок «Социальное самочувствие» включал в себя, во-первых, балльную оценку субъективной удовлетворенности состоянием дел в стране в политической, экономической, социальной и культурной сферах от 1 до 5 баллов, во-вторых, степень уверенности в завтрашнем дне. Для сравнения выделенных групп респондентов по оценкам социального самочувствия и вероятности наступления позитивных и негативных событий в стране рассчитывались средние баллы. Значимость различий в оценках между исследуемыми группами молодежи измерялась с помощью коэффициентов сопряженности Крамера. Для сравнения средних баллов использовался коэффициент Эта.

\section{Анализ результатов исследования}

Политическая самоидентификация провластной и оппозиционной молодежи. Основу выбора той или иной стратегии политического участия составляет ценностная и идейная идентификация. Идеологический спектр, включающий в себя наиболее устоявшиеся в общественном сознании идейнополитические течения, положен нами в основу методики измерения политической самоидентификации молодежи. Отдельно мы выделили вариант ответа, в котором респонденты выражают отрицание приверженности каким-либо идеологическим постулатам, что, на наш взгляд, не означает размытую или неопределенную идентификацию, а скорее допускает некоторую эклектичность политических взглядов.

В первую очередь обращает на себя внимание факт наличия значительного числа респондентов, отрицающих свою приверженность определенной политической идеологии среди активистов-сторонников, - число тех, кто не причисляет себя ни к какому идеологическому течению составляет более $40 \%$, затрудняющихся идентифицировать свои идейно-по- 
литические взгляды - 17 \% (табл. 1). Среди оппозиционных активистов таких значительно меньше - $27 \%$, а затруднившихся определить свои взгляды нет вообще.

Такая ситуация может объясняться рядом причин. Во-первых, реальная политическая деятельность, с которой молодые активисты успели познакомиться на практике, значительно шире и многообразнее тех установок, которые задаются идеологией. Во-вторых, стоит констатировать, что сама по себе российская политика на современном этапе мало зависит от идейных программ, а в основном строится на прагматических конъюнкурных соображениях. В-третьих, функцию политической социализации в обществе реализуют многочисленные политические партии и объединения, которые также демонстрируют либо полное безразличие идеологии, либо практикуют идейную всеядность. Активистысторонники, вовлекаясь в построенные властью механизмы политической социализации, активно взаимодействуют с правящими группами и перенимают не только стиль их поведения, но и идейные установки.

Наибольшее число активистов-оппозиционеров разделяют либеральные или либертарианские взгляды (50\%). Среди активистовсторонников таких оказалось $14 \%$. Популярность либеральных взглядов среди оппозиционеров широко известна. Они составляют основу общего посыла артикулируемых претензий к власти, среди которых традиционно на первом месте стоят ущемления гражданских прав и свобод, подавление оппозиции, сворачивание демократических процедур и прочее.

Общей чертой обеих групп респондентов стала непопулярность радикальных взглядов. Число тех, кто идентифицирует себя с коммунистической, анархистской или националистической идеологией, крайне мало. Среди активистов-сторонников - $6 \%$; среди активистов-оппозиционеров - $12 \%$. Таким образом, можно констатировать, что подавляющее большинство опрошенных придерживается умеренных взглядов на общественно-политические процессы, что вселяет определенный оптимизм. Тем самым молодые активисты демонстрируют понимание того, что радикальные взгляды и связанные с ними методы в политике не могут принести долгосрочного позитивного результата.

Мотивы общественно-политического участия молодежи. Предлагаемые респондентам к оценке мотивы участия можно условно разделить на две группы - в первую мы отнесли мотивы, в основе которых лежат социоцентристские ценности - значимость защиты прав человека, гражданского общества и гражданской активности, а во вторую - в основе которых лежат индивидуалистические ценности: значимость личного успеха, признания, самореализации в политике. Согласно полученным результатам конфигурация мотивов участия в общественно-политической жизни практически сходна у представителей обеих групп политически активной молодежи (см. табл. 2).

Политическая самоидентификация молодых активистов, \%

\begin{tabular}{|l|c|c|}
\hline Приверженцем каких политических взглядов Вы себя & \multicolumn{2}{|c|}{ Формы политической активности } \\
\cline { 2 - 3 } могли бы назвать? & $\begin{array}{c}\text { Активисты- } \\
\text { сторонники }\end{array}$ & $\begin{array}{c}\text { Активисты- } \\
\text { оппозиционеры }\end{array}$ \\
\hline $\begin{array}{l}\text { Не придерживаюсь каких-то конкретных взглядов, } \\
\text { политика намного шире и сложнее этих стереотипов }\end{array}$ & 40,4 & 27,3 \\
\hline Социал-демократические взгляды & 15,2 & 6,2 \\
\hline Консерватизм & 7,3 & 1,4 \\
\hline Коммунизм & 2,6 & 0,0 \\
\hline Либерализм / либертарианство & 13,9 & 50,7 \\
\hline Анархизм & 1,3 & 8,2 \\
\hline Национализм & 1,3 & 4,1 \\
\hline Другое & 0,0 & 0,8 \\
\hline Затрудняюсь ответить & 17,9 & 1,4 \\
\hline \multicolumn{2}{|r|}{} \\
\hline
\end{tabular}

Примечание. Коэффициент V Крамера [0..1]: 0,550; вероятность ошибки (значимость): 0,000. 
Прежде всего, молодых людей мотивирует значимость гражданской активности как таковой, необходимости защищать свои права. Она находится в верхней строке рейтинга мотивов как среди активистов-сторонников, так и среди активистов-оппозиционеров. Тем не менее среди оппозиционно настроенной молодежи он более значим и явно доминирует - его отметили более $80 \%$ респондентов, тогда как среди провластно настроенной молодежи его указали только 56 \%. На втором месте - потребность в построении более справедливого общества. Эгоцентричные мотивы - желание сделать карьеру политика, peaлизовать свои способности и таланты, - не столь значимы для обеих групп респондентов, однако для активистов-сторонников они все же имеют более существенное значение (39\% и $31 \%$ ), чем для оппозиционно настроенной молодежи (12\% и $21 \%)$.

Таким образом, мотивация, связанная с осознанием необходимости защиты своих прав, значима в политическом участии обеих групп респондентов. Это свидетельствует о том, что они являются носителями активистского типа гражданской культуры. Различия между ответами респондентов исследуемых групп, на наш взгляд, сопряжены с особенностями приобретаемого в процессе политической социализации опыта: в то время как представители группы сторонников власти выстраивают свою индивидуальную траекторию в политике на основе взаимодействия с государственными структурами, активно участвуют в проектах, предлагаемых политическим истеблишмен- том, представители оппозиционной группы приобретают опыт скорее конфликтного взаимодействия, опыт противостояния, которое подчас выходит за рамки правового поля.

Образ социального будущего. Основным моментом в изучении образа будущего, сложившегося в сознании исследуемых групп молодежи, выступило сопоставление общественного идеала, которое мы назвали «образом желаемого будущего», и социальных ожиданий молодежи, то есть «образа ожидаемого будущего».

С одной стороны, мы наблюдаем сходство в оценках запросов на высокий уровень благосостояния общества: основными ориентирами общественного развития для обеих групп молодежи выступают высокий уровень жизни в обществе (62\% и $73 \%)$, развитие высоких технологий (44 \% и $64 \%$ ), эффективная рыночная экономика ( $40 \%$ и $64 \%$ ). С другой стороны, просматриваются заметные различия в оценках значимости и роли государства. Если оппозиционная молодежь почти не выражает запрос на сильное государство, то сторонники власти, напротив, имеют выраженные этатистские ориентации (см. табл. 3).

Образ желаемого будущего можно увязать с политической идентификацией. Ценности рыночной экономики, гуманизма, толерантности выступают признанными основами либеральной идеологии. В то же время ценности сильного государства, его влиятельность на мировой политической арене - это основа консерватизма.

Таким образом, несмотря на сходные ценностные ориентиры среди обеих групп

Таблииа 2

Мотивы участия в общественно-политической жизни политически активной молодежи, \%

\begin{tabular}{|l|c|c|}
\hline $\begin{array}{l}\text { В чем лично Ваши мотивы участия в общественно- } \\
\text { политической жизни? }\end{array}$ & $\begin{array}{c}\text { Формы политической активности } \\
\text { Акторонники }\end{array}$ & $\begin{array}{c}\text { Активисты- } \\
\text { оппозиционеры }\end{array}$ \\
\hline $\begin{array}{l}\text { Это вопрос наших прав, убежден, что все граждане } \\
\text { должны быть активны и участвовать в общественно- } \\
\text { политической жизни }\end{array}$ & 56,1 & 81,3 \\
\hline $\begin{array}{l}\text { Меня интересуют проблемы построения более спра- } \\
\text { ведливого общества }\end{array}$ & 37,8 & 57,6 \\
\hline $\begin{array}{l}\text { Я бы хотел достичь успеха на этом поприще и сделать } \\
\text { карьеру политического или общественного деятеля }\end{array}$ & 38,5 & 11,8 \\
\hline $\begin{array}{l}\text { Это мне интересно, здесь я могу приложить свои спо- } \\
\text { собности и таланты }\end{array}$ & 31,1 & 21,5 \\
\hline $\begin{array}{l}\text { Меня вдохновляет опыт и авторитет выдающихся лю- } \\
\text { дей, моих близких и знакомых }\end{array}$ & 17,6 & 11,8 \\
\hline \multicolumn{1}{|c|}{ Итого } & 181,1 & 184,0 \\
\hline
\end{tabular}


респондентов, возможные способы достижения этих ценностей-целей значительно различаются: для активистов-сторонников власти инструментом достижения высокого уровня благосостояния выступает сильное государство, которое призвано решить основные социально-экономические проблемы общества. В то же время респонденты-оппозиционеры явно выражают запрос на снижение функций государства в общественной жизни, автономизацию гражданских структур. Базой для решения социально-экономических проблем выступает высокий уровень технологического развития и рыночная экономика.

Значимые различия между активистамисторонниками и активистами-оппозиционера- ми обнаружены и в образе «ожидаемого», или «вероятного», будущего (табл. 4).

У провластной молодежи преобладают смешанные ожидания будущего развития событий. Так, в экономической сфере респонденты опасаются наступления спада и ускорения темпов инфляции, а в социальной сфере - нарастания конфликтов в обществе. Наиболее выражены $(3,14)$ негативные ожидания, связанные с международной изоляцией России. Напротив, высоко оцениваются позитивные тенденции и вероятность достижения успехов в науке, искусстве, культуре $(3,44)$, развитие наукоемких отраслей экономики $(3,23)$, успехи в укреплении правовых основ государства $(3,07)$. Таким образом, сознанию активистов-сторон-

Идеалы общественного развития политически активной молодежи, \%

\begin{tabular}{|l|c|c|}
\hline Существует множество точек зрения на идеал общественного раз- & \multicolumn{2}{|c|}{ Политическая активность } \\
\cline { 2 - 3 } $\begin{array}{l}\text { вития, какие из них разделяете лично Вы? (необходимо выбрать не } \\
\text { более 3 вариантов ответа) }\end{array}$ & $\begin{array}{c}\text { Aктивисты- } \\
\text { сторонники }\end{array}$ & $\begin{array}{c}\text { Активисты- } \\
\text { оппозиционеры }\end{array}$ \\
\hline Общество эффективной рыночной эконо мики & 40,4 & 63,7 \\
\hline Общество с высоким уровнем жизни & 62,3 & 72,6 \\
\hline $\begin{array}{l}\text { Общество, ориентиро ванное на развитие высоких техноло- } \\
\text { гий }\end{array}$ & 43,7 & 63,7 \\
\hline Общество равенства и справедливости & 47,7 & 32,2 \\
\hline Гуманистическое общество & 17,2 & 29,5 \\
\hline Общество, с которым считаются другие страны & 22,5 & 8,9 \\
\hline Общество с сильной государственной властью & 41,1 & 2,1 \\
\hline Толерантное общество, терпимое к меньшинствам & 14,6 & 34,9 \\
\hline Общество, где высоко ценят традиции предков & 16,6 & 4,8 \\
\hline & & 312,3 \\
\hline
\end{tabular}

Таблииа 4

Оценка молодежью вероятности наступления позитивных или негативных событий в будущем (1 - наименее вероятное, 5 - наиболее вероятное), средний балл

\begin{tabular}{|c|c|c|}
\hline \multirow{2}{*}{$\begin{array}{l}\text { Оцените вероятность наступления позитивных или негативных } \\
\text { событий в ближайшем будущем }\end{array}$} & \multicolumn{2}{|c|}{ Политическая актив ность } \\
\hline & $\begin{array}{l}\text { Активисты- } \\
\text { сторонники }\end{array}$ & $\begin{array}{c}\text { Активисты- } \\
\text { оппозиционеры }\end{array}$ \\
\hline \multicolumn{3}{|c|}{ Оценка вероятности позитивных событий } \\
\hline Экономический рост & 2,87 & 1,45 \\
\hline Укрепление рубля & 2,72 & 1,63 \\
\hline Формирование социального консенсуса & 2,93 & 2,04 \\
\hline Усп ехи россиян в науке, искусстве, культуре & 3,44 & 2,24 \\
\hline Успехи в укреплении правовых основ государства & 3,07 & 1,63 \\
\hline $\begin{array}{l}\text { Развитие наукоемких отраслей экономики, создание рабо- } \\
\text { чих мест }\end{array}$ & 3,23 & 1,67 \\
\hline \multicolumn{3}{|l|}{ Оценка вероятности негативных событий } \\
\hline Экономический спад & 2,93 & 4,30 \\
\hline Ускорение темпов инфляции & 2,95 & 3,99 \\
\hline Нарастание конфликтов в обществе & 3,07 & 4,10 \\
\hline Изоляция России на внешнеполитической арене & 3,14 & 4,34 \\
\hline Ограничение прав и свобод граждан & 2,85 & 4,55 \\
\hline Нарастание безработицы, снижение благосостояния граждан & 2,89 & 4,28 \\
\hline
\end{tabular}


ников присуща определенная парадоксальность: они не усматривают противоречий между наличием успехов в наукоемких отраслях экономики, созданием рабочих мест, с одной стороны, и экономическим спадом - с другой. Такая форма сознания может объясняться тем, что именно молодежь, активно взаимодействующая с властными институтами, в наибольшей степени подвержена восприятию официального дискурса о стратегических направлениях развития России, свидетельствующих о ее успехах и неудачах.

Оппозиционная молодежь демонстрирует однозначность оценок будущего, в которых преобладает негативизм. Особенно он присущ ожиданиям событий в экономической сфере, где высоко оцениваются вероятность экономического спада $(4,30)$; нарастания безработицы, снижение благосостояния граждан $(4,28)$. В своей практической политической деятельности оппозиционеры регулярно встречаются с ограничительным воздействием государственных структур, поэтому высокая оценка вероятности наступления таких событий вполне логична $(4,55)$.

Сопоставляя образы желаемого и ожидаемого будущего, мы можем диагностировать определенное рассогласование социальных идеалов и социальных ожиданий молодежи, причем среди активистов-оппозиционеров оно, разумеется, выражено намного острее. Напомним, что, оценивая идеалы и ориентиры общественного развития, молодые активисты на первые места поставили именно экономические показатели: эффективную экономику, развитие технологий, улучшение уровня жизни. При этом среди наиболее вероятных ожидаемых событий - экономический спад (4,3 - среди активистов-оппозиционеров и даже 2,93 - среди провластной молодежи). Для оппозиционной молодежи противоречие между желаемым и ожидаемым образами будущего кроме диссонанса в экономическом развитии, затрагивает, прежде всего, сферу правовых отношений: важным ориентиром выступает гуманистическое общество, терпимое к меньшинствам, а наиболее вероятным событием - ограничение прав и свобод граждан.

Социальное самочувствие и настроение. Дисбаланс между социальным идеалом и ожидаемым направлением развития событий в ближайшей перспективе обусловливает пессимистические социальные настроения среди молодых людей и неудовлетворенность текущим состоянием дел в различных общественных сферах. Исследование показало, что молодые сторонники власти ощущают достаточно высокую степень уверенности в завтрашнем дне - в той или степени чувствуют уверенность почти $80 \%$ респондентов и только $16 \%$ не уверены, тогда как среди оппозиционно настроенных молодых людей наблюдается прямо противоположная картина: только $15 \%$ выражают ту или иную степень уверенности (при этом определенно уверены в завтрашнем дне вообще менее $1,5 \%$ ), и более $80 \%$ респондентов-оппозиционеров не уверены или скорее не уверены, чем уверены, в завтрашнем дне (см. табл. 5).

Однако если перейти от общей оценки уверенности в будущем к более конкретной оценке актуальной ситуации в обществе в различных его сферах - экономике, политике, социальной сфере и культурной жизни (см. табл. 6), то можно заметить следующее.

Критичный настрой в оценке текущих дел характерен не только для активистов-оппозиционеров, хотя, разумеется, их удовлетворенность положением дел существенно ниже, чем у активистов-сторонников, но и последние дают достаточно негативные оценки: средние баллы удовлетворенности состоянием и развитием дел в стране - 3,00 или немногим выше (за исключением культурной жизни - 3,32), а в экономике - значительно ниже трех и составляет 2,68.

Очевидно, что, хотя и активисты-сторонники смотрят в будущее более оптимистично, нежели оппозиционная молодежь, неудовлетворенность текущей ситуацией и некоторое негативное социальное самочувствие по этому поводу в определенной степени характерно и для провластно настроенной молодежи.

Таким образом, настрой одной группы молодежи связан с надеждами на позитивные изменения системы «изнутри», что определяет адаптивное и относительно бесконфликтное освоение политических ролей. В то же время настрой оппозиционных активистов предполагает более или менее жесткое противостояние с властными структурами и не- 
Я.В. Дидковская, Д.В. Трынов. Политически активная молодежь: стратегии политического участия

верие в возможность реформирования без качественных трансформаций власти.

Стратегии политического участия. Одна из установок, которая однозначно объединяет две обследуемые группы, это стремление состояться в общественно-политической роли. Причем здесь речь идет не только о настоящем, но и о будущем. Путь в политику может лежать через разные сценарии и поведение. Совершенно очевидно, что одна группа молодежи демонстрирует стремление со- трудничать с властью, видит свои возможности и шансы преуспеть в нынешних политических условиях и делает ставку на участие в создаваемых государством механизмах вовлечения молодежи в политику. Другая группа стремится заявить о себе через протестное взаимодействие и даже через противостояние с властью.

Респонденты обеих групп имеют опыт политической деятельности на постоянной основе (табл. 7). Для активистов-сторонников

Таблица 5

Уверенность в завтрашнем дне политически активной молодежи, \%

\begin{tabular}{|l|c|c|}
\hline \multirow{2}{*}{$\begin{array}{c}\text { Чувствуете ли Вы уверенность } \\
\text { в завтрашнем дне? }\end{array}$} & \multicolumn{2}{|c|}{ Политическая активность } \\
\cline { 2 - 3 } & $\begin{array}{c}\text { Активисты- } \\
\text { сторонники }\end{array}$ & $\begin{array}{c}\text { Активисты- } \\
\text { оппозиционеры }\end{array}$ \\
\hline Да & 41,2 & 1,4 \\
\hline Скорее да, чем нет & 37,9 & 13,7 \\
\hline Затрудняюсь ответить & 3,9 & 3,4 \\
\hline Скорее нет, чем да & 9,2 & 32,9 \\
\hline Нет & 7,2 & 48,6 \\
\hline & 100,0 & 100,0 \\
\hline
\end{tabular}

Примечание. Коэффициент V Крамера [0..1]: 0,681; вероятность ошибки (значимость): 0,000.

Таблицуа 6

Оценка молодежью дел в стране (1 - идут в совершенно неправильном направлении; 5 - идут в совершенно правильном направлении), средний балл (индекс)

\begin{tabular}{|l|c|c|}
\hline Насколько дела в стране сейчас идут в пра- & \multicolumn{2}{|c|}{ Политическая активность } \\
\cline { 2 - 3 } вильном или неправ ильном направлении? & $\begin{array}{c}\text { Активисты- } \\
\text { сторонники }\end{array}$ & $\begin{array}{c}\text { Активисты- } \\
\text { оппозиционеры }\end{array}$ \\
\hline В эко номике & 2,68 & 1,27 \\
\hline В политике & 3,09 & 1,23 \\
\hline В социальной сфере & 3,00 & 1,36 \\
\hline В культурной жизни & 3,32 & 1,82 \\
\hline
\end{tabular}

Таблица 7

Виды общественно-политической деятельности молодежных активистов, \%

\begin{tabular}{|c|c|c|}
\hline \multirow{2}{*}{$\begin{array}{l}\text { Какими видами общественно-политической деятельности Вы } \\
\text { занимались в последние } 3 \text { месяца? (можно выбрать неограни- } \\
\text { ченное количество ответов) }\end{array}$} & \multicolumn{2}{|c|}{ Политическая активность } \\
\hline & $\begin{array}{l}\text { Активисты- } \\
\text { сторонники }\end{array}$ & $\begin{array}{l}\text { Актив исты- } \\
\text { оппозиционеры }\end{array}$ \\
\hline Оказывал помощь ветеранам, инвалидам, престарелым & 39,5 & 7,6 \\
\hline $\begin{array}{l}\text { Участвовал в волонтерских акщиях, спортивных куль- } \\
\text { турных и спортивных мероприятиях }\end{array}$ & 80,3 & 47,2 \\
\hline $\begin{array}{l}\text { Принимал участие в работе молодежных объединений } \\
\text { (правительства, парламента, общественной палаты, по- } \\
\text { литических партий и т. д.) }\end{array}$ & 65,1 & 22,9 \\
\hline $\begin{array}{l}\text { Участвовал в подгото вке законопроекта (иного государ- } \\
\text { ственного решения) }\end{array}$ & 7,2 & 1,4 \\
\hline $\begin{array}{l}\text { Участвовал в забасто вках, антиправительственных пике- } \\
\text { тах, митингах, шествиях }\end{array}$ & 17,8 & 91,7 \\
\hline Принимал участие в работе правозащитных организаций & 11,8 & 16,7 \\
\hline Создавал и организо вывал сбор подписей под петицией & 3,9 & 17,4 \\
\hline $\begin{array}{l}\text { Выполнял функции помощника депутата (советника } \\
\text { должностного лица) }\end{array}$ & 6,6 & 0,7 \\
\hline Другое & 2,0 & 1,7 \\
\hline Итого & 234,2 & 207,3 \\
\hline
\end{tabular}


более характерно участие в одобряемых властью видах деятельности. Основное поле, где они могут применить свои силы на сегодняшний момент, - волонтерство и социальная помощь нуждающимся (81 \%); участие в работе молодежных объединений (правительства, парламента, общественной палаты, политических партий $(65,1$ \%).

Вторая группа участвует в забастовках, антиправительственных пикетах, митингах, шествиях $(91,7)$; в волонтерских акциях, спортивных культурных и спортивных мероприятиях (47,2 \%); в деятельности правозащитных организаций $(16,7 \%)$; в создании петиций и сборе подписей $(17,4 \%)$.

Важным ориентиром в поведении человека является степень готовности к защите своих взглядов, ценностей, идеалов в условиях, когда он может встретиться со значительными издержками в виде испорченных отношений с коллегами, руководством и потерей работы. Это готовность пойти на конфликт в отстаивании своей правоты. Мы смоделировали ситуацию, в которой респондентам было предложено избрать линию поведения в потенциально конфликтной ситуации. Как видно из результатов, респонденты демонстрируют разную степень готовности отстаивать свои моральные принципы (табл. 8). При этом отстаивание позиции происходит в ситуации неравенства сторон в конфликте, что связано с обладанием разных ресурсов власти. Следовательно, мы можем экстраполировать ситуацию на реализацию стратегий поведения в структуре властных отношений.

Стратегии поведения первой группы молодежи вполне укладываются в такие конструкты, как «активный конформизм» или «активная адаптация». В поисках своих шансов в политической сфере они готовы мириться с некоторыми моральными издержками, идти на компромисс и проявляют готовность сглаживать острые углы. Большинство опрошенных (28 \%) считают, что вступать в конфликт глупо, потому что им ничего не добиться.

Политическая социализация второй группы респондентов проходит в качественно иных, более сложных условиях, нежели у первой группы. Вместо адаптивной стратегии вхождения в политическую жизнь избрана «активистско-протестная». Она имеет массу издержек, что отражено в показателях социального самочувствия, но вместе с тем респонденты проявляют высокий уровень правового идеализма. Среди активистов-оппозиционеров мы видим большую однородность идей и взглядов и вместе с этим приверженность идеалам в политической деятельности. Одним из индикаторов этого выступает готовность идти на конфликт, защищая свои взгляды и убеждения, даже в ситуациях, связанных с возможными потерями $(41,7$ \%).

\section{Заключение}

Исследованием зафиксировано, что выбираемые молодежью стратегии политического участия зависят от сложившегося в их сознании образа социального будущего, а именно от степени согласованности общественных идеалов и социальных ожиданий молодежи.

Таблича 8

\section{Стратегии поведения респондентов в прожективной конфликтной ситуации, \%}

\begin{tabular}{|c|c|c|}
\hline Предположим, в своей деятельности Вы столкнулись с тем, что & \multicolumn{2}{|c|}{ Политическая активность } \\
\hline $\begin{array}{l}\text { Ваш начальник нечист на руку. Пойдете ли Вы на открытый } \\
\text { конфликт с ним, зная, что это может привести к самым негатив- } \\
\text { ным последствием (увольнение, испорченные отношения, пло- } \\
\text { хие рекомендации и пр.) для Вас? }\end{array}$ & $\begin{array}{l}\text { Активисты- } \\
\text { сторонники }\end{array}$ & $\begin{array}{c}\text { Актив исты- } \\
\text { оппозиционеры }\end{array}$ \\
\hline $\begin{array}{l}\text { Пошел бы в случае необходимости на конфликт, не заду- } \\
\text { мываясь о последствиях, такое нельзя допускать }\end{array}$ & 13,9 & 41,7 \\
\hline $\begin{array}{l}\text { Попытался отстраниться и держаться подальше от него, но } \\
\text { в конфликт вступать не стал }\end{array}$ & 19,2 & 18,8 \\
\hline $\begin{array}{l}\text { У него есть свой начальник, сообщил бы ему об этом, } \\
\text { пусть разбираются }\end{array}$ & 21,9 & 22,9 \\
\hline Нет, это глупо, конфликтом ничего не добиться & 28,5 & 3,5 \\
\hline Затрудняюсь ответить & 16,6 & 13,2 \\
\hline Итого & 100,0 & 100,0 \\
\hline
\end{tabular}


Рассогласование общественного идеала и ожиданий у провластно настроенной молодежи проявляется незначительно и не оказывает негативного влияния на ее социальнополитическую социализацию, в результате ей присущи относительно высокие оценки удовлетворенности и уверенности в завтрашнем дне. Существенное рассогласование социальных идеалов и ожидаемого варианта развития событий у оппозиционно настроенной молодежи формирует у активистов-оппозиционеров не только резко критическое восприятие настоящего, но и пессимистические настроения относительно будущего.

Тем не менее мы отмечаем и позитивные моменты, зафиксированные нашим исследованием. Было подтверждено, что вопреки устоявшимся в последние годы представлениям об апатии и пассивности молодежи, среди нового поколения существует слой политических активистов, обладающих достаточно сформированной правовой и гражданской культурой. При этом молодые политические активисты, как оппозиционно, так и провластно настроенные, не подвержены радикальным политическим взглядам и экстремистским побуждениям, что позволяет надеяться на возможность становления новой взвешенной политической элиты.

\section{ПРИМЕЧАНИЕ}

${ }^{1}$ Статья подготовлена в рамках проекта «Молодежь как субъект политики: социальное самочувствие и стратегии политической карьеры в контексте гражданской активности», реализуемого при поддержке РФФИ и АНО ИЭСИ, № 19-011-31601.

The reported study was funded by RFBR and ANCO EISR according to the research project "Youth as a subject of politics: social well-being and strategies of a political career in the context of civic activism" no. 19-011-31601.

\section{СПИСОК ЛИТЕРАТУРЫ}

Александрова, Ненахова 2017 - Александрова О.А., Ненахова Ю.С. Рабочая смена: восполнит ли молодежь кадровый дефицит в промышленности и аграрно-промышленном комплексе? // Мониторинг общественного мнения: экономические и социальные перемены. 2017. № 6. С. 216-231.
Алмонд, Верба 2014 - Алмонд Г., Верба С. Гражданская культура. Политические установки и демократия в пяти странах. М.: Мысль, 2014.

Артюхина 2017 - Артюхина В.А. Осмысление социального протеста в современной социологии: анализ основных подходов // Социологические исследования. 2017. № 11. С. 30-34.

Гаврилюк и др. 2016 - Гаврилюк В.В., Мехришвили Л.Л., Скок Н.И., Садыкова Х.Н., Фарахутдинов Ш.Ф., Маленков В.В., Гаврилюк Т.В., Сотков О.Л., Голиков И.Н. Образ будущего в оценках нового поколения россиян: монография. Тюмень: ТИУ, 2016.

Горшков, Шереги 2010 - Горшков М.К., Шереги Ф.Э. Молодежь России: социологический портрет. М.: ЦСПиМ, 2010.

Дидковская, Дулина, Трынов 2018 - Дидковская Я.В., Дулина Н.В., Трынов Д.В. Образ социального будущего молодежи индустриального региона (на примере Волгоградской и Свердловской областей) // Logos et Praxis. 2018. T. 17. № 3. C. 35-44. DOI: https://doi.org/ 10.15688/lp.jvolsu.2018.3.5.

Елишев 2013 - Елишев С.О. Молодежь в современных политических процессах // Перспективы науки. 2013. № 7 (46). С. 113-119.

Ефанова 2011 - Ефанова Е.В. Политический экстремизм и протестная активность молодежи России // Научные ведомости Белгородского государственного университета. Серия: История. Политология. Экономика. Информатика. 2011. № 20. С. 234-239.

Милорава 2017 - Милорава А.Р. Процесс политической социализации молодежи в современном российском обществе // Молодой ученый. 2017. № 13. С. 505-507.

Санина 2016-Санина А.Г. Патриотизм и патриотическое воспитание в современной России // Социологические исследования. 2016. № 5. С. 44-53.

Смакотина 2009 - Смакотина Н.Л. Политическая активность молодежи: результаты социологического исследования. М.: МАКС Пресс, 2009.

Соболева, Смирнова, Чудаева 2016 - Соболева C.В., Смирнова Н.Е., Чудаева О.В. Демографическая ситуация в России: настоящее и будущее // Мир новой экономики. 2016. № 3. С. 106-115.

Трынов 2012 - Трынов Д.В. Методологические аспекты исследования образа будущего в контексте становления гражданской культуры // Социология и общество: глобальные вызовы и региональное развитие: Материалы IV Очередного Всерос. социол. конгресса (г. Уфа, 23-25 октября 2012 г.). М.: РОС, 2012. C. 134-139. 
Чирун 2011 - Чирун С.Н. Причины и формы политического экстремизма в молодежной среде транзитивного общества (региональный аспект) // Социум и власть. 2011. № 4 (32). C. $44-48$.

Яницкий 2012 - Яницкий О.Н. Митинги повсюду: реабилитация гражданского активизма России // Общественные науки и современность. 2012. № 3. C. 58-68.

Campante, Chor 2012 - Campante Filipe R., Chor D. Schooling political participation, and the economy // Review of Economics and Statistics. 2012. № 94 (4). P. 841-859.

Kofi, Melvin 2013 - Kofi C.K., Melvin S.Jr. Employment, wages and voter turnout // American Economic Journal: Applied Economics. 2013. № 5 (4). P. 111-143.

\section{REFERENCES}

Aleksandrova O.A., Nenakhova Yu.S., 2017. Personnel shift: will the youth make up for the shortage of staff in the production sector and in the Agroindustrial Sectors. Monitoring of public opinion: economic and social changes, vol. 6 , pp. 216-231.

Almond G., Verba C., 2014. Civic culture. Political attitudes and democracy in five countries. Moscow, Mysl' Publ.

Artjukhina V.A., 2017. Sociological interpretation of social protest: reviewing basic contemporary approaches. Sotsiologicheskie issledovaniya, vol. 11, pp. 30-34.

Gavriluk V.V., Mehrishvili L.L., Skok N.I., 2016. Image of future in assessments of new generation of Russians. Tumen', TIU.

Gorshkov M.K., Sheregi F.E., 2010. Russian Youth: sociological portrait. Moscow, TsSPiM.

Didkovskaya Y.V., Dulina N.V., Trynov D.V., 2018. The image ofthe social future ofthe young people in industrial region (in the context of the Volgogradand Sverdlovsk regions). Logos et
Praxis, vol. 17, no. 3, pp. 35-44. DOI: https:// doi.org/10.15688/lp.jvolsu.2018.3.5.

Elishev S.O., 2013. Youth in modern political processes. Perspektivy nauki, vol. 7 (46), pp. 113-119.

Efanova E.V., 2011. Political extremism and protest activity of youth of Russia. Nauchnye vedomosti Belgorodskogo gosudarstvennogo universiteta, vol. 20, pp. 234-239.

Milorava A.P., 2017. Political extremism and protest activity of youth of Russia. Molodoy uch'oniy, vol. 13, pp. 505-507.

Sanina A.G., 2016. Patriotism of Russians and patriotic education in modern Russia. Sotsiologicheskie issledovaniya, vol. 5, pp. 44-53.

Smakotina N.L., 2009. The political activity of youth: the results of a sociological study. Moscow, MAKS Press.

Soboleva S.V., Smirnova N.E., Chudaeva O.V., 2016. The demographic situation in Russia: present and future. Mir novoy ekonomiki, vol. 3, pp. 106-115.

Trynov D.V., 2012. Methodological aspects of the study of future image in the context of civic culture development. Sotsiologia I obtshestvo: global'nye vyzovy i regional'noe razvitie: Materialy IV ocherednogo vserossiyskogo sotsiologicheskogo kongressa (Ufa, October 23-25, 2012). Moscow, ROS, pp. 134-139.

Chirun S.N., 2011. The reasons and forms of political extremism in the youth policy of the transitive society (regional aspect). Sotsium I vlast', vol. 4, pp. 44-48.

Janitsky O., 2012. Rehabilitation of Civil Activism in Russia; Peasantry and the Power in the History of Russia the $20^{\text {th }}$ Centuries. Social sciences and contemporary world, vol. 3, pp. 58-68.

Campante Filipe R., Chor D., 2012. Schooling political participation, and the economy. Review of Economics and Statistics, no. 94 (4), pp. 841-859.

Kofi C.K., Melvin S.Jr., 2013. Employment, wages and voter turnout. American Economic Journal: Applied Economics, no. 5 (4), pp. 111-143. 
Я.В. Дидковская, Д.В. Трынов. Политически активная молодежь: стратегии политического участия

\section{Information about the Authors}

Yana V. Didkovskaya, Doctor of Sciences (Sociology), Associate Professor, Professor, Department of Sociology and Technology of Public and Municipal Administration, Ural Federal University, Mira St., 19, 620002 Yekaterinburg, Russian Federation, I.V.Didkovskaia@urfu.ru, https://orcid.org/0000-0001-9525-9514

Dmitriy V. Trynov, Senior Lecturer, Department of Sociology and Technology of Public and Municipal Administration, Ural Federal University, Mira St., 19, 620002 Yekaterinburg, Russian Federation, DV.Trynov@urfu.ru, https://orcid.org/0000-0001-9534-4073

\section{Информация об авторах}

Яна Викторовна Дидковская, доктор социологических наук, доцент, профессор кафедры социологии и технологий государственного и муниципального управления, Уральский федеральный университет, ул. Мира, 19, 620002 г. Екатеринбург, Российская Федерация, I.V.Didkovskaia@urfu.ru, https://orcid.org/0000-0001-9525-9514

Дмитрий Валерьевич Трынов, старший преподаватель кафедры социологии и технологий государственного и муниципального управления, Уральский федеральный университет, ул. Мира, 19, 620002 г. Екатеринбург, Российская Федерация, DV.Trynov@urfu.ru, https:/orcid.org/0000-0001-9534-4073 